\title{
Assessment of the opportunities and threats of Maggaia- Lamido River Basin communities in Sokoto, Nigeria
}

\author{
Muhammad Muktar Namadi, ", Mohammed Yau ${ }^{1}$, Faruruwa Mohammed Dahiru ${ }^{1}$, \\ Manu Haruna Isa ${ }^{2}$, Katsina Sani Mamman ${ }^{3}$ \\ ${ }^{1}$ Chemistry Department, Nigerian Defence Academy, Kaduna, Nigeria \\ ${ }^{2}$ RightLinks Integrated Services Limited Kaduna, Nigeria \\ ${ }^{3}$ Desertification Control Dept. Federal Ministry of Environment Abuja, Nigeria
}

Email address:

ammimuktar@yahoo.com(Muhammad, M. N.)

\section{To cite this article:}

Muhammad Muktar Namadi, Mohammed Yau, Faruruwa Mohammed Dahiru, Manu Haruna Isa, Katsina Sani Mamman. Assessment of the Opportunities and Threats of Maggaia-Lamido River Basin Communities in Sokoto, Nigeria. Journal of Water Resources and Ocean Science. Vol. 2, No. 4, 2013, pp. 49-55. doi: 10.11648/j.wros.20130204.11

\begin{abstract}
This paper investigates the environmental challenges associated with the management and utilization of Maggaia-Lamido River Basin, Sokoto State, Nigeria. It also identified the spatial distribution of communities whose means of livelihood depends heavily on the river basin under study. The paper identified that the most important environmental challenge is how to maintain the land base resource on which the economies of the local people are founded. The land base itself is challenged by desertification and behind this ecological problem stands increasing human pressures, such as, overgrazing, felling of trees for fuel, over cultivation of marginal lands etc. The results are escalating tension and conflict between villages and communities and increasing poverty, which further undermine the prospects for addressing the problems. Without significant change, environmental degradation will continue to step up within the communities like Kalmalo, Gidan Kaura and Tajaye- huchi and the natural resource base on which people's livelihood depend on will continue to decline. Equally, this paper identified the prospects of Maggaia-Lamido river basin and proposed a paradigm shift to an innovative community based Integrated Water Resource Management (IWRM) strategy to serve as a catalyst for poverty reduction and increase societal resilience to the impact of climate change.
\end{abstract}

Keywords: Problems, Prospects, Water Resource Management, River Basin

\section{Introduction}

Water is life and essential resource that supports existence of both animals and plants. It plays a key role in the metabolic breakdown of essential molecules such as protein and carbohydrates. Of the five basic human needs (water, food, health, education, peace) water is a common factor to the other four. Water supply is central to life and civilization (CSD, 2000). While the efficiency of food production depends on water availability, most society's socio-economic activities largely rely on both quantity and quality of water. Though, water is present everywhere, its use has always been constrained in terms of availability, quantity and quality (Biswas, 2004). Water has been a very important factor in settlement development in the country where it usually serves as human settlement boundaries (FGN, 2004). Water is constantly in motion, passing from one location to another, which makes its rational planning and management a very complex and difficult task. According to the Food and Agricultural Organization, out of the global available water resource, only $0.3 \%$ of it is freshwater (UN-HABITAT, 2008).

Freshwater is inland water that is fit for both agricultural and industrial uses and for human consumption. One of the sources of freshwater is river. A river may pass through several settlements and hence adjacent communities could benefit from the various services it provides such as drinking water, fishing, irrigation, domestic use etc. River Basin referred to as drainage system or basin, represents a system of interconnected system of water tributaries that flow towards single outlet (Longe et al., 2010). It combines the natural processes of precipitation, surface and ground water runoff with man-made features such as dams and reservoirs and hydro-power projects, diversions and irrigation schemes, industrial and residential water and 
environmental and cultural protection services (Global Water Partnership, 2003). Therefore, the aim of this paper is to assess the problems and prospects of Maggaia-Lamido River Basin and make recommendations in line with Community Based Integrated Water Resource Management principles.

\section{Methodology}

The methodology of this study involved review of available literatures and field survey. The desk review entailed searching national and international publications on community practices on natural resources utilization in the dry land ecosystems. Each practice area was theoretically assessed with respect to its capacity to promote sustainability in water resources management, management of vegetative cover, dry land farming, natural resource management, drought preparedness and coping capacity, pastoral development and management. Such an appraisal of existing research and coping mechanisms with environmental challenges in dry lands, permits the development of a conceptual framework for the identification of key issues that needed to be explored or clarify during the field survey that centered on consultation with local communities, policy and decision makers, researchers and scientists, on land use and conservation issues. Working within the broad spectrum of the Integrated Water Resource Management, this study employed the exploratory and topical Rapid Rural Appraisal (RRA) in the interview and field survey, using semi-structured group and individual interviews.

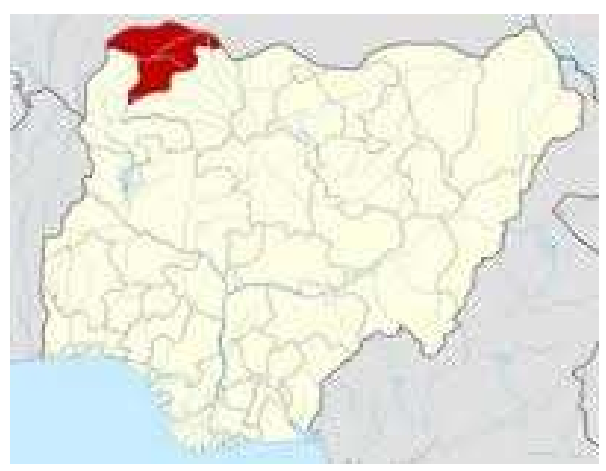

Fig 1: Map of Nigeria showing Sokoto state.

\section{Overview of Maggia-Lamido River Basin}

The Maggia River takes its source in Niger Republic and after $140 \mathrm{~km}$, the river enters Nigeria via Birnin-Konni in Sokoto State Nigeria, after which the river is called Lamido (FMEnv 2002). After about $8 \mathrm{~km}$, the river flows into Lake Kalmalo (see figure 2). The basin has a total land area of $4,138 \mathrm{~km}^{2}$. While about $2,119 \mathrm{~km}^{2}(51 \%)$ of the water basin is in Niger Republic, Nigeria accounts for the balance $2,019 \mathrm{~km}^{2}$ representing $49 \%$. Essentially, the river contains water only between July and October with annual discharge varying between 3 to $92 \mathrm{~mm}$ per year (Agunbiade, 2002). A significant part of the river is captured in ponds and does not reach Lake Kalmalo. In Nigeria the water from Lake Kalmalo is used for drinking, irrigation and fishing. The Maggaia-Lamido River Basin cuts across Illela, Gwadabawa, Wurno, Goranyo, Gada, Sabon-Birni Local Government Areas of Sokoto State.

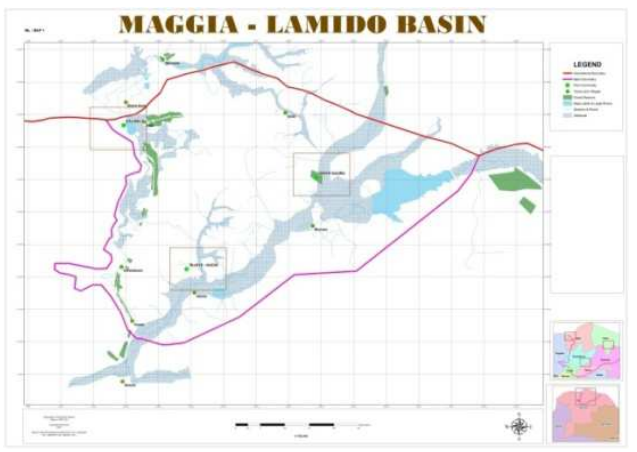

Fig 2: Map of Maggaia-Lamido River Basin

Table 1: GPS location of settlements around the River Basin

\begin{tabular}{ll}
\hline Settlement & GPS Coordinates \\
\hline Kalmalo & $05^{0} 14^{\prime} 37.35 \mathrm{E}: 13^{0} 43^{\prime} 20.58 \mathrm{~N}$ \\
Munwadata & $5^{0} 16^{\prime} 2.52 \mathrm{E}: 13^{0} 41^{\prime} 37.98 \mathrm{~N}$ \\
Runi & $05^{0} 12^{\prime} 27.53 \mathrm{E}: 13^{0} 41^{\prime} 53.23 \mathrm{~N}$ \\
Jema & $05^{0} 10^{\prime} 54.66 \mathrm{E}: 13^{0} 43^{\prime} 9.78 \mathrm{~N}$ \\
Gidan Kaura & $05^{0} 44.15 \mathrm{E}: 13^{0} 35^{\prime} .17 \mathrm{~N}$ \\
Kaddi & $05^{0} 43^{\prime} 50.57 \mathrm{E}: 13^{0} 36^{\prime} 8.31 \mathrm{~N}$ \\
GidanGyado & $05^{0} 43^{\prime} 21.15 \mathrm{E}: 13^{0} 37^{\prime} 37.31 \mathrm{~N}$ \\
GidanKashim & $05^{0} 44^{\prime} 8.74 \mathrm{E}: 13^{0} 38^{\prime} 43.87 \mathrm{~N}$ \\
Huchi & $05^{0} 26^{\prime} 44.53 \mathrm{E}: 13^{0} 22^{\prime} 5.95 \mathrm{~N}$ \\
Tajaye & $05^{0} 26^{\prime} 37.95 \mathrm{E}: 13^{0} 22^{\prime} 18.08 \mathrm{~N}$ \\
Salame & $05^{0} 2434.81 \mathrm{E}: 13^{0} 22^{\prime} 26.92 \mathrm{~N}$ \\
\hline
\end{tabular}

\section{Biophysical Characteristics of Communities around the Basin}

Climate: The communities lie within the semi arid region of northern Nigeria characterized by long dry season and very short rainy season. Average rainfall within the region is quite low, at roughly $250 \mathrm{~mm}$ per year. The rainy season starts usually in June and ends in September. The dry season on the other hand stretches from October to May. Temperatures are high throughout the year with annual average of $35^{\circ} \mathrm{C}$. However during the cool harmattan seasons (November - February), the temperatures range between $20^{\circ} \mathrm{C}-25^{\circ} \mathrm{C}$. The relative humidity ranges between $28 \%$ in the dry season to $68 \%$ in the rainy season. The average wind speed ranges between $145 \mathrm{~km} / \mathrm{h}$. $230 \mathrm{~km} / \mathrm{h}$ (Water Resources, 2006). Topography and Drainage: The area is of gently sloping terrain $\left(1^{0}-3^{0}\right)$, drained by the seasonal Kalmalo stream. Lake Kalmalo that 
used to be perennial and the fadama areas have completely dried up. The ground water depth is more than $60 \mathrm{~m}$ (ICRISAT, NA).

Soil: there are basically two soil types across the length and breadth of the six local government areas, namely Red Acid Sands and Yellow and Brown Acid Sands (UNDP/FAO, 1969). The Red Acid Sands are derived from eolian and fluviated deposits of Sangiwa, Tureta, Sokoto and Illela formations. The soils occur on flat to gently undulating terrains and the external drainage is good. The A horizons vary in thickness and are usually brown to reddish brown, fine to medium sands. They are virtually structure less or weak sub angular blocky, always very fragile and loose. The underlying horizons consist of yellowish red, loamy sands with weak sub angular blocky structure, very friable when moist, soft when dry and extend to a considerable depth. The PH values of the top layers show high acidity at less than 5 but there is a gradual increase in $\mathrm{PH}$ with depth, though it seldom exceeds 6 even in the lowest layers. The organic carbon content in the A horizon varies from 0.15 to $0.30 \%$. Due to coarse texture, both permeability and infiltration rates are very rapid at 5 to $10 \mathrm{~m} /$ hour or more and water holding capacity is low to very low, often less than $2 \mathrm{~m}$ of moisture in the top $2 \mathrm{ft}$ of soil.

Yellow and Brown Acid Sands: The A horizon vary in thickness from $6-25$ in and consist of brown to pale brown fine sands with little or no structure. The consistence is friable to very friable when moist, slightly hard when dry. The underlying horizons consist of yellowish to pale brown or strongly fine sands to loamy sands, friable or very friable when moist to slightly hard to hard when dry. The structure is porous massive or weak sub angular blocky. The organic carbon content in the A horizon varies from $0.2-0.5 \%$ and the $\mathrm{pH}$ values show wide variation from $4-6.7$. Both permeability and infiltration rates are very rapid and water holding capacity are very low. The soils with good external drainage and occurring on flat to gently undulating terrains are derived from eolian or fluviatile sediments of the Sangiwa, Sokoto, Tureta, Rabah, Zazagawa and Argungu formation (Agunbiade, 2002).

Vegetation/Forest \& Grazing Reserves: The vegetation is of Sudan savannah type comprising of short grasses, shrubs and scattered trees. A forest reserve of about $60 \mathrm{~km}^{2}$ consisting of mostly 'neem trees' has been established in the area. A grazing reserve covering an area of about $10 \mathrm{~km}^{2}$ has also been established to serve as an important rainy season grazing area for transhumant pastoralists as well as for the herds of the sedentary farmers. The vegetation equally consists of scattered grasses and drought resistant trees. Common trees and shrubs found are Acacia albida (Gawo), Acacia nlotica (Bagaruwa), Acacia seyal (Farin Kaya), Balanite etc. Common Pest/Weed: Common pests in the community that present threat to agricultural production include quela birds, locust, Termites and rodents (Agunbiade, 2002).

\section{Socio-Economic Characteristics, Environmental Challenges and Traditional Responses}

Demography: Based on 2006 population census, the six local government areas through which the Maggaia-Lamido river basin traverse have the total population of one million one hundred and eighteen thousand three hundred and sixteen people $(1,182,316)$ as shown in table 2 .

Table2: population of the six Local governments

\begin{tabular}{llll}
\hline Local Govt. Area & Male & Female & Total \\
\hline Illela & 66112 & 84377 & 150489 \\
Gwadabawa & 118150 & 113208 & 231358 \\
Wurno & 83343 & 78964 & 162307 \\
Goronyo & 91694 & 90602 & 182296 \\
Gada & 122844 & 25423 & 248267 \\
SabonBirni & 99247 & 108352 & 207599 \\
Grand Total & $\mathbf{5 8 1 3 9 0}$ & $\mathbf{5 0 0 9 2 6}$ & $\mathbf{1 1 8 2 3 1 6}$ \\
\hline
\end{tabular}

Source: NPC, 2006

Farming is the major economic activity in the area. Majority of the people are subsistence farmers engaging in both rain fed farming and fadama farming. Crops grown in the dry season under fadama farming include onion, tobacco, rice and maize. Crops grown under rain fed farming on the other hand include millet, sorghum, maize, and cowpea. Kalmalo is one of the major areas producing large quantity of onion within the basin and Sokoto state at large. Animal rearing is another important economic activity in Kalmalo area. Animals particularly cattle, sheep and goats are kept by both the Fulani pastoralists and sedentary Hausa farmers as symbol of wealth and source of income. Fishing used to be important in the community, but this has completely stopped due to the drying up of Lake Kalmalo. The major constraints to farming in the area are, drought, active sand dunes burying prime farmlands, weeds, pests, lack of farm implements and poor means of transportation. Similarly, the major constraints to livestock rearing in the area include; inadequate grazing reserve to accommodate the growing animal population, scarcity of dry season fodder, inadequate water points for the animals and lack of vet nary facilities.

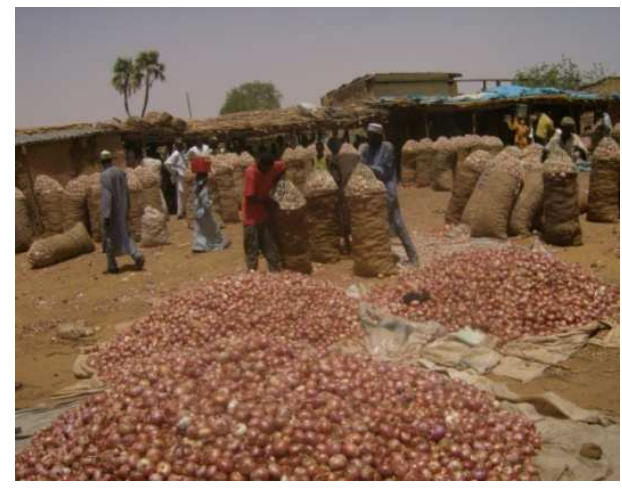

Fig. 3: Onion Market - Kalmalo 


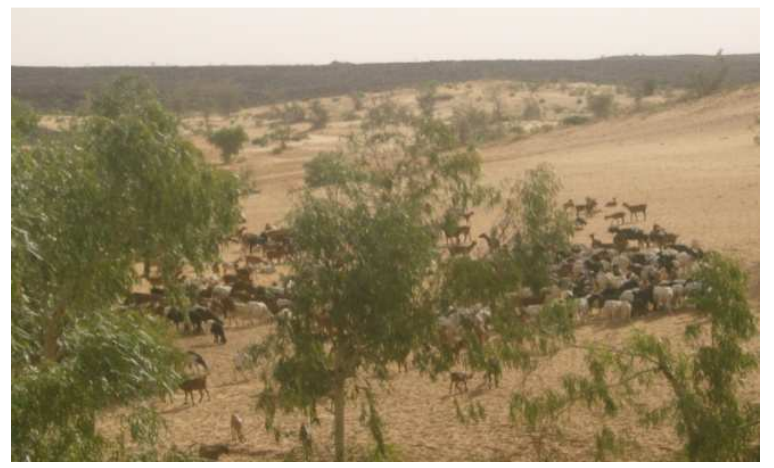

Fig. 4: Fulani pastoralist Searching for Pasture - Gidan Kaura

Sources of Energy: Fuel wood and animal dung are the major sources of energy for domestic use in the communities. Cutting down of trees contributes to the process of desertification and land degradation in the area, while the use of animal dung deprives the soils of organic materials. Lack of alternative energy sources, poverty, level of illiteracy and increasing population has exacerbated the problem. There is also complete absent of either Government or civil society intervention to address these challenges.

Drinking Water Supply: Water shortage particularly in the dry season has been identified as the most critical challenge facing most of the communities. Between the months of June - September, the river serves the communities with drinking water. While in the dry season, the entire community in most cases depends on a single hand dug well as source of water for drinking and other domestic uses (see figure $5 \& 6$ ). The water drown from well or River is used directly without treatment. This has resulted to serious health problems in most communities around the basin.

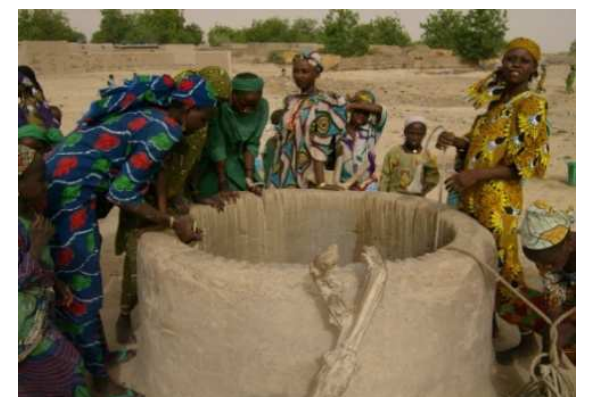

Figure 5: Hand dug well in Kalmalo Community

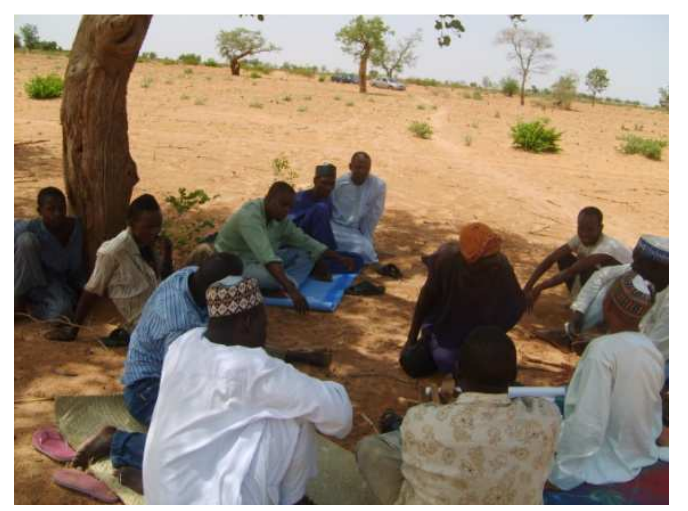

Figure 6: Focus group discussion with the community members

Opportunities and Threats of the River Basin The persistent ecological challenges facing the communities around the river basin over the years has resulted in devising local adaptation strategies which increase their resilience to the impacts of draught and climate change. This community based approaches ranges from water resource management to land use, farming practices and energy supply. The community responses to the recurrent environmental challenges are summarized in table 3 .

Table 3: Environmental Challenges and Traditional Responses

\begin{tabular}{|c|c|c|c|}
\hline S/No & Environmental Challenge & Impact & Response \\
\hline 1 & Active sand dunes & $\begin{array}{l}\text { Burying of farmlands, settlements, roads and } \\
\text { other facilities } \\
\text { Reduced agricultural production } \\
\text { Forced migration of people and animals }\end{array}$ & $\begin{array}{l}\text { Use of palm leaves and straws to stabilize } \\
\text { the some dunes }\end{array}$ \\
\hline 2 & Drought & $\begin{array}{l}\text { Declined crop yield } \\
\text { Famine } \\
\text { Acute water shortage } \\
\text { Drying up of water bodies } \\
\text { Loss of livestock } \\
\text { Increased poverty } \\
\text { Forced migration }\end{array}$ & $\begin{array}{l}\text { Planting of drought resistant and short maturing } \\
\text { crops. } \\
\text { Engagement in off - farm activities } \\
\text { Sales of stored grains and animals } \\
\text { Migration out of the area }\end{array}$ \\
\hline 3 & Wind Erosion & Land degradation & Tree planting \\
\hline 4 & Declined soil fertility & Reduced crop production & $\begin{array}{l}\text { Organic fertilizer (manure) } \\
\text { Mixed cropping }\end{array}$ \\
\hline 4 & Pests & Destruction of crops & Use of pesticides \\
\hline 5 & Drying up of Kalmalo Lake & $\begin{array}{l}\text { Reduced farming and fishing activities } \\
\text { Lack of water for people and animals } \\
\text { Migration of people and livestock out of the } \\
\text { area } \\
\text { Increased unemployment } \\
\text { Reduced household income }\end{array}$ & No response \\
\hline
\end{tabular}


The Magga-Lamido river basin provides some vital services to the communities around it, some of these services include; drinking water and fishes. Table 4 presents some highlights of the prospects and challenges of the basin.

Table 4: Prospect and Challenges of Maggaia River Basin

\begin{tabular}{|c|c|}
\hline Strengths & $\begin{array}{ll}\text { - } & \text { Fishing } \\
\text { - } & \text { Irrigation } \\
\text { - } & \text { Water supply scheme } \\
\text { - } & \text { Aquatic life } \\
\text { Agriculture }\end{array}$ \\
\hline Weaknesses & $\begin{array}{ll}\text { - } & \text { Flooding } \\
\text { - } & \text { Scarcity of dry season fodder } \\
\quad & \text { Dradequate water supply } \\
& \text { affects up of Lake Kalma cultivation } \\
\text { - } & \text { Recurrent drought } \\
\text { Erratic rainfall } \\
\quad \text { Needs and pests } \\
\quad \text { No institutional presence } \\
\quad \text { Lack of facilities, utilities and services }\end{array}$ \\
\hline Opportunities & $\begin{array}{ll}\text { - } & \text { IWRM } \\
\text { - } & \text { Transportation } \\
\text { - } & \text { Recreation } \\
\text { - } & \text { Econvironmental sustainability } \\
\text { - } & \text { Ecological balance }\end{array}$ \\
\hline Threats & $\begin{array}{l}\text { - } \text { Climate change } \\
\text { Drop in water level/shrinking of water } \\
\text { bodies } \\
\text { - } \quad \text { Dead of aquatic life } \\
\text { - } \quad \text { Communal conflict } \\
\text { - } \quad \text { Sand degradation } \\
\text { Pollution of water from the use of } \\
\text { fertilizers }\end{array}$ \\
\hline
\end{tabular}

\section{Integrated Water Resource Management}

Integrated Water Resources Management (IWRM) refers to a process that promotes the coordinated development and management of water, land and related resources, in order to maximize the resultant economic and social welfare in an equitable manner without compromising the sustainability of vital ecosystems (ODA, 1996). It is also defined as a participatory planning and implementation process, based on sound science, which brings together stakeholders to determine how to meet society's long-term needs for water and coastal resources while maintaining essential ecological services and economic benefits (IUCN, 2006; Agishi, 2002). Generally, IWRM seeks to protect the environment, promote economic growth and engender sustainable agricultural development, support democratic participation in governance, and improve human health.

The key elements which IWRM tends to uphold are; coordinated process that brings together stakeholders, focuses on both economic and social welfare and equity as well as protecting ecosystems, uses scientific tools and data to provide sound base for judgment and emphasizes proper governance involving democratic participation (World Bank Institute, 2006). The implementation of IWRM involved a logical sequence of phases that is supported by continuous events some of which are; initial planning process, vision statement that guide the future direction of the management process. Other events include situational analysis that elucidates the types of solutions deem necessary based on the water needs of the primary beneficiaries. It equally identifies the strengths and weaknesses in water resource management, points out the aspects that should be addressed in order to improve the situation and guides the path for attainment of stated vision. Selecting the suitable strategy is another important event in the implementation of IWRM. Taking a cue from the vision, the situation analysis, and the water resources strategy, an IWRM plan may be prepared. Its note worthy that IWRM is a participatory approach to water resources management where major stakeholders, communities and policy makers are brought together to come up with solutions that are environmentally sustainable, economically efficient and socially inclusive so as to maintain ecological balance of river basins.

It is against this background and our strong believe that community based natural resource management which springs from genuine community demand can nurture enterprises that both generate considerable income and improve the state of local ecosystems. These enterprises could be scale up to achieve a significant poverty reduction effect. Such stride could also be achieved through the implementation of community based approaches that agrees with the principle of IWRM. In the case of MaggaiaLamido river basin therefore, the paper seeks to propose the followings;

a. Community Based Integrated Water Resource Management: The introduction of community based solutions calls for awareness building measures as well as organizational and technical support. Community based organization (CBO \& NGO) and community leaders may provide essential inputs towards building community capacity for water resource management. This is in view of the fact that Community-based water arrangements should be allowed to play their full roles paramount to the sustainability of the people's immediate environment. Indeed, both the public sector and community-based water arrangements have their strengths and weaknesses as assessed, and the key question is not which one is best, but rather which combination is most likely appropriate to address needs in specific areas and in particular for those most at risk and the vulnerable rural poor women and men of Maggaia -Lamido River Basin communities. 


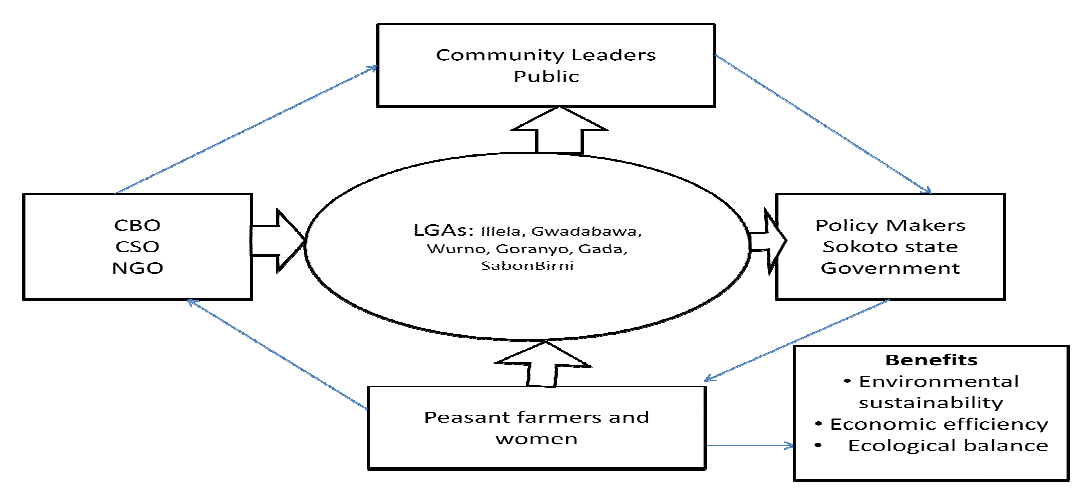

Fig 7: Proposed Community Based Integrated Water Resource Management Framework.

\section{Task of each of the above proposed stakeholders:}

LGAs: the six local governments through which the Maggaia-Lamido river basin pass through should provide logistics and counterpart funding and equally apply pressure on the Sokoto state to put in place necessary policy options

CBOs, CSO, NGO: these stakeholders would articulate the positions of the communities and apply pressure on the local government departments responsible for works and water supply.

Policy Makers: The state government through the ministries of Environment and Water resources should initiate an Integrated Water Resource Management action plan with clear vision, mission and objectives with definite timeline.

Community leaders and the general public: in line with bottom up approach to planning issues, the community should be engaged in thorough consultation processes to identify areas of felt needs and available sustainable options. This is with the view to accentuate what is working for the local communities.

Peasant farmers and women: these are the primary beneficiaries of any local based project.

b. Water harvesting: Climate change is to a great extent water change. Water is the primary medium through which climate change impacts will be felt by humans and the environment. The Impact of Climate change on water cuts across all sectors; therefore there is urgent need to embark on water harvesting measures so as to ensure full utilization of rain water.

The paper also proposed interventions based on Identified Priority Needs and weaknesses of the Communities along Maggaia-Lamido River basin (see table 5). Implementation of these interventions would potentially improve the livelihood of the communities and address poverty.

Table 5: Identified Priority Needs of the Community

\begin{tabular}{|c|c|c|c|c|c|}
\hline $\begin{array}{l}\text { Environmental } \\
\text { Rehabilitation \& } \\
\text { Conservation }\end{array}$ & Alternative Energy & Infrastructure & Agriculture & $\begin{array}{l}\text { Water } \\
\text { Management/ } \\
\text { Supply }\end{array}$ & Poverty Alleviation \\
\hline $\begin{array}{l}\text { 1.Rehabilitation of } \\
\text { abandoned gypsum mining } \\
\text { sites } \\
\text { 2.Afforestation including } \\
\text { agro forestry } \\
\text { 3.Establishment of } \\
\text { rangelands to } \\
\text { accommodate the growing } \\
\text { livestock population } \\
\text { 4. Rehabilitation of } \\
\text { existing grazing land and }\end{array}$ & $\begin{array}{l}\text { 1. Woodlot } \\
\text { establishment } \\
\text { 2. Solar Energy } \\
\text { 3. Biogas } \\
\text { 4. Provision of } \\
\text { Efficient wood stove }\end{array}$ & $\begin{array}{l}\text { 1. Road } \\
\text { 2. Skill development } \\
\text { center } \\
\text { 3. Health centre } \\
\text { 4. School } \\
\text { 6 Community centre }\end{array}$ & $\begin{array}{l}\text { 1.Provision of } \\
\text { fertilizer } \\
\text { 2. Provision of } \\
\text { credit facilities } \\
\text { 3. provision of } \\
\text { tractor hire } \\
\text { services }\end{array}$ & $\begin{array}{l}\text { 1. Provision of } \\
\text { boreholes } \\
\text { 2.Construction of } \\
\text { dam } \\
\text { 3. Rain water } \\
\text { harvesting facility }\end{array}$ & $\begin{array}{l}1 \text { Skill acquisition } \\
\text { centre } \\
2 \text { Credit facilities }\end{array}$ \\
\hline
\end{tabular}

\section{Conclusion}

In the final analysis, Maggaia-Lamido River Basin has indeed its strengths and weaknesses and the adjoining communities are the direct beneficiaries of these strengths and equally contribute to its deteriorations and current climate change issues have further worsen the already appalling situations. It is envisioned that Maggaia-Lamido River Basin could serve as a toolkit against poverty and environmental degradations evident in the communities along the basin only if the Authorities accentuate on what is working for the people. Integrated Water Resource Management is all encompassing, for its put into considerations community input, policy makers, and other stakeholders in the designing of water management processes. It is by so doing that felt needs could be identified and alternative means can be integrated to promote environmental sustainability and check the 
devastating effect of climate change on both human and the environment.

\section{Reference}

[1] Agishi E (2002). National Report (Livestock Resources) on IEM Federal Ministry of Environment Abuja, Nigeria.

[2] Agunbiade O.E (2002). National Report (Water Resources) on IEM Federal Ministry of Environment Abuja, Nigeria.

[3] Biswas A.K (2004). Integrated Water Resource Management: A Reassessment of Water Forum Contributions. Water International; 29(2)

[4] CSD, (2000). Commission on Sustainable Development : Integrated planning and management of land resources. Decision $8 / 3$.

[5] Encarta (2006), Water. Encarta Microsoft ltd

[6] FMEnv., (2002). National Report on Integrated Management of Natural Resources in the Transboundary Areas of Nigeria \& Niger

[7] FGN, (2004). National Water Policy. Available online: www.waterresources.gov.ng/assets/ (Accessed May, 2013)

[8] Longe E.O., Omole D.O., Adewumi I.K. and Ogbiye A.S., (2010). Water Resources Use, Abuse and Regulations In Nigeria. Journal of Sustainable Development in Africa; $12(.2)$.
[9] NPC (2006): National Population Census, Federal Government of Nigeria.

[10] Global Water Partnership (2003): Integrated Water Resource Management Toolbox, version 2. Available online: www.iboro.ac.uk/well/resource/publ. (Accessed: 29/5/2013)

[11] Global Water Partnership (2000): Integrated Water Resource Management. Available online: www.iwawawiki.org/xwiki/bin/ (Accessed: 28/5/2013).

[12] Gadzama N.M (2002): National Report (Biodiversity) on IEMFed. Mins. Of Environment

[13] ICRISAT (NA). Integrated Ecosystem Management in the Trans-boundary Areas between Nigeria and Niger.

[14] IUCN (2006).Catchment Management Plan for Integrated Natural Resources Management of Komadugu - Yobe Basin

[15] Kolawale A (2002). National Report on Socio - Economic \& Cultural Characteristics Federal Ministry of Environment Abuja, Nigeria.

[16] ODA (1996). Renewable Natural Resources Profile NigeriaNatural Resources Institute

[17] UNDP/FAO (1969). Soil \& Water Resources Survey of the Sokoto Valley; Final Report. 5(1).

[18] UN-HABITAT. 2008. State of the World's Cities 2008-2009.

[19] Water Resources, (2006). Nigeria Support to the Federal Ministry of Water Resources: Water Resources Management and Policy: Lot No 2; COWI A/S. 